\title{
Geochemical studies of carbonates of the Tayiba Formation (Upper Eocene), Abu Zenima area, West Central Sinai
}

\author{
Esmat A. Abou El-Anwar(i)
}

\begin{abstract}
Background: Tayiba Formation situated at the entrance of Wadi El-Tayiba. It unconformably overlies the Late Eocene Tanka Formation and unconformably underlies the Early Miocene Nukhul Formation. Severely authors studied this formation geologically, stratigraphically, and petrographically. But, geochemical studies on the rare earth elements to illustrate the depositional environments are seldom.

Results: Results were revealed that, mineralogically, the carbonate rocks in the Tayiba Formation are mainly composed of calcite, dolomite, quartz and clay minerals. The terminal parts of the studied Tayiba Formation are more dolomitized relative to the middle beds.

Geochemical analysis revealed that the carbonates of Tayiba Formation were deposited under shallow, oxidizing, marine environment. The dolomitization process has taken place in marine environment. Carbonate rocks of the Tayiba Formation are highly enriched in trace elements and highly to moderately rare earth elements. The studied carbonate rocks characterized by light REE (LREE) enrichment than heavy REE (HREE).

Conclusions: The redox-sensitive and rare earth elements study indicates that the carbonate rocks in the Tayiba Formation were deposited under anoxic to oxic marine environment. Also, the trace and rare earth elements values indicated that the studied carbonate rocks are mainly hydrogenous sources. These elements may be derived from more mafic sources.
\end{abstract}

Keywords: Abu Zenima, Tayiba Formation, Geochemistry, Rare earth elements

\section{Introduction}

Tayiba Formation has a considerable importance to the history of the opening of the Red Sea and the Gulf of Suez. This formation represented a transitional stage between the pre-rifting Eocene marine sediments and the Early Miocene transgression of the newly formed rift (Refaat and Imam 1999).

Lithostratigraphically, the exposed Eocene successions in the south-western part of Sinai are mainly carbonate. The Eocene succession thickness recorded at Wadi Tayiba is about $152 \mathrm{~m}$ (Ibrahim et al. 2016).

Tayiba Formation is located at the mouth of Wadi ElTayiba. It unconformably overlies the Late Eocene Tanka Formation (interbedded chalky limestone and

Correspondence: abouelanwar2004@yahoo.com

Geological Sciences Department, National Research Center, 33 El Bohouth St. (former El Tahrir St.)- Dokki, POB: 12622, Giza, Egypt shale with argillaceous limestone) and unconformably underlies the Early Miocene Nukhul Formation. This is significant with polymictic conglomerate beds characteristic of the unconformable surfaces (El Barkooky and ElAraby 1999). Also, they mentioned which conformable up change from shallow marine carbonates (Tanka Formation) to tidally influenced shallow marine clastics and carbonates (Tayiba Formation) indicate a swallowing of water depth during the Late Oligocene. Jackson et al. (2006) revealed that the Tayiba Formation represented slight changes in relative sea level. In addition, Van Wagoner et al. (1988) mentioned that the eustatically or tectonically driven sea-level drop leads to the pre-rift/syn-rift contact unconformity. Refaat and Imam (1999) mentioned that at Wadi El-Tayiba, the Tayiba Formation is composed of marine, yellow red siltstone and mudstone, alternating with reddish-yellow and grayish argillaceous to sandy 
limestone, highly fossiliferous with reworked Nummulites spp. and molluscan shell fragments.

\section{Materials and methods}

Fifteen representative samples were collected from the carbonate rocks of Abu Zenima, Tayiba Formation in West Central Sinai. Mineralogically, three selected samples were investigated by the $\mathrm{X}$-ray technique at the Egyptian Mineral Resources Authority (Dokki, Egypt) using a PAN analytical X-Ray Diffraction equipment model X'Pert PRO with Secondary Monochromator; Cu-radiation $(\lambda=1.542 \AA)$ at 45 K.V., 35 M.A., and scanning speed $0.02 \%$ sere used. The diffraction charts and relative intensities are compared with ICDD files. Eight samples were selected to determine the chemical composition by using Axios Sequential WD_XRF Spectrometer, Analytical 2005 in the National Research Center laboratories. ASTM E 1621 standard guide for elemental analysis by wavelength dispersive X-Ray Fluorescence Spectrometer, and ASTM D 7348 standard test methods for loss of ignition (LOI) of solid combustion. The fabric and the size of the synthesized samples were characterized via SEM coupled with energy-dispersive spectroscopy EDAX (SEM Model Quanta FEG 250),

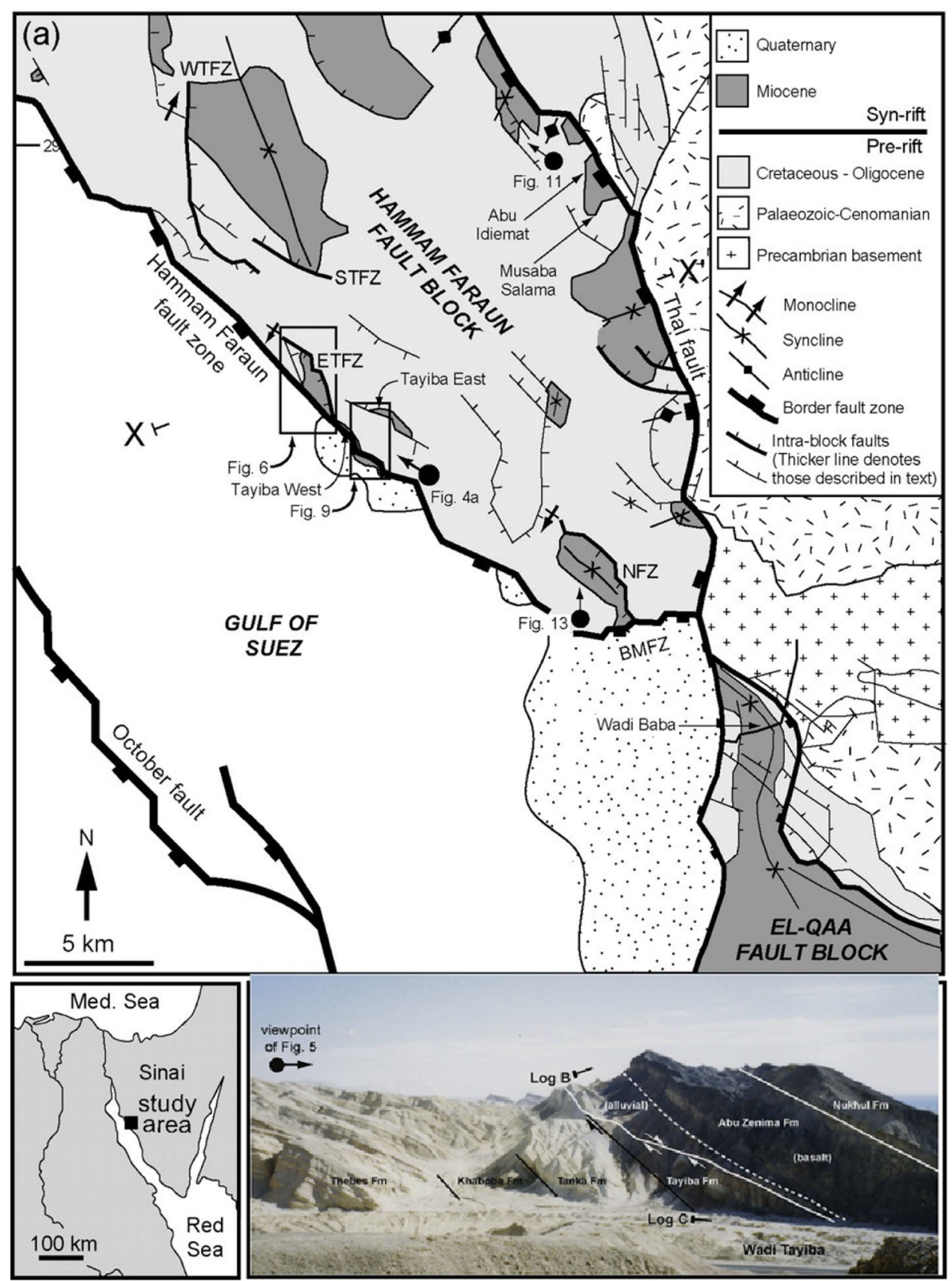

Fig. 1 Photograph stratigraphic correlation through the Wadi Tayiba. Modified from Jackson et al. (2006) 


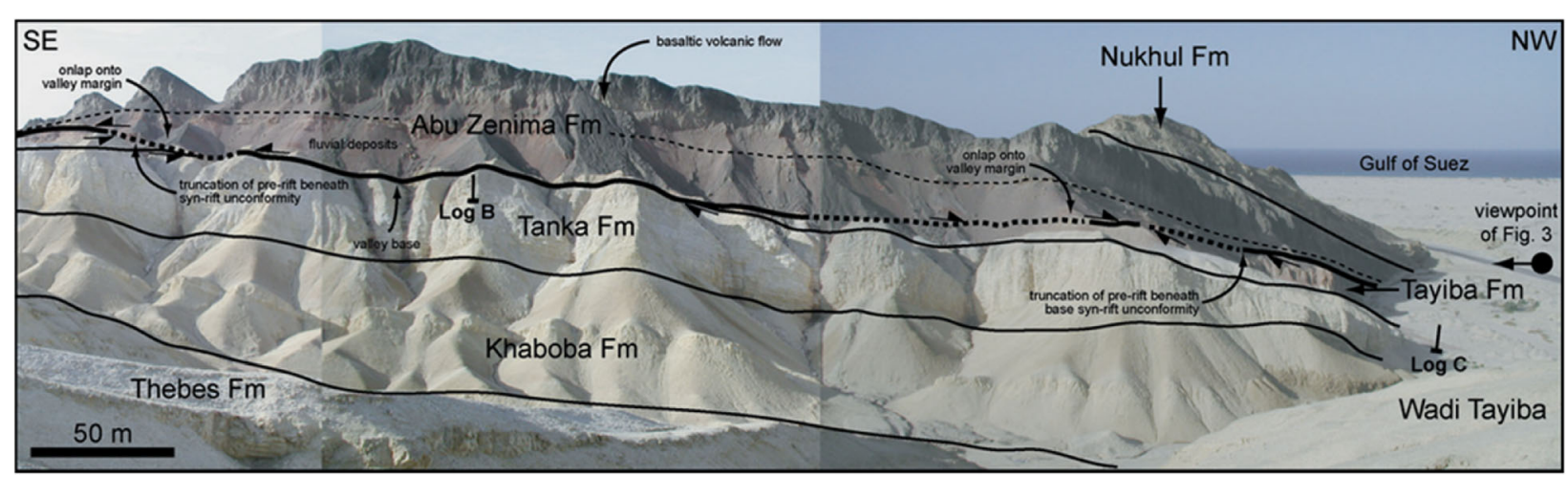

Fig. 2 Photograph map SE showing the stratigraphic section at the entrance to Wadi Tayiba, appearance Thebes, Khaboba, Tanka and Tayiba formations overlain by alluvial and volcanic deposits of the early syn-rift Abu Zenima Formation across a major sequence boundary (after Christopher Aiden-Lee)

carried out in the National Research Center laboratories. The samples were selected based on their hand specimen description to represent the formation for chemical and mineralogical studies.

\section{Geologic setting}

Abu Zenima area is located on the eastern part of the Gulf of Suez, west-central Sinai (Fig. 1). The stratigraphical sequence ranges in age from late Cretaceous to middle Miocene. In Abu Zenima area, the Tayiba Red Beds (Hume et al. 1920) or Tayiba Formation (Youssef and Abdel Malik 1969) consists generally of red shale and sandstone with polymictic conglomerate and subordinate argillaceous to sandy limestone beds. Two major unconformity surfaces are represented with obvious basal polymictic conglomerate beds. This formation was underlying the Middle Eocene Tanka Formation and overlying the Early Miocene Abu Zenima Formation. Wadi Tayiba is located about $2 \mathrm{~km}$ north of the village of Abu Zenima.

All previous studies indicate that the oldest pre-rift unit in the Wadi Tayiba is the Upper Eocene Tanka Formation, which consists of micritic, pelletoidal limestones, containing a range of shallow water benthic foraminifera (e.g., Quingelocuina sp.) According to the faunal assemblage, the Tanka Formation was deposited on a carbonate platform in an upper shelf environment (Abul-Nasr and Thunell 1987).

Late pre-rift marine carbonates, mudstones and sandstones of the Thebes, Khaboba, Tanka and Tayiba formations are erosively overlain by alluvial and volcanic deposits of the early syn-rift Abu Zenima Formation transversely a major sequence boundary (Jackson et al. 2006) (Fig. 2).

The aim of the present work is to study the mineral and chemical composition of the carbonate rocks of the Tayiba Formation (Upper Eocene) in Abu Zenima area to reveal their depositional environments and if there is a possibility of utilizing them in some purposes.

\section{Results}

Chemically, the studied samples composed mainly of $\mathrm{CaO}$ (26.39\%), $\mathrm{SiO}_{2}$ (25.93\%), $\mathrm{Al}_{2} \mathrm{O}_{3}$ (10.67\%), $\mathrm{Fe}_{2} \mathrm{O}_{3}$ (3.13\%), $\mathrm{MgO}(1.88 \%)$, and $\mathrm{Na}_{2} \mathrm{O}$ (1.26\%). Mineralogically, the studied carbonate rocks at Tayiba Formation, Upper Eocene, Abu Zenima area, are consisting of calcite and dolomite as well as clay minerals. Dolomitization was the main diagenetic features encountered in the carbonate rocks of Tayiba Formation. Table 1 shows the chemical analysis data for major, trace, and rare earth elements of the studied carbonate rocks and the relation between them quoted in Table 2 .

\section{Discussion}

\section{Mineralogy}

X-ray diffraction XRD analyses were carried out on some selected samples. X-ray patterns revealed that the dominating minerals in the studied samples are mainly dolomite and calcite, quartz in addition to clay minerals.

\section{Geochemistry \\ Major elements}

Chemical analysis data of major, trace, and rare earth elements are quoted in Table 1. The normative dolomite content of the studied samples ranges from 4.3 to $11.44 \%$, averaging $8.61 \%$. Calcite precipitated from seawater would contain from 5.9 to $27.1 \% \mathrm{MgCO}_{3}$ by weight, while calcite exposed to meteoric water diagenesis will lose most of its magnesium content (Moore, 1989 and Morse and Mackenzie, 1990). The studied carbonate rocks contain up to $8.67 \% \mathrm{MgCO}_{3}$ and $6.52 \%$, in average. This value revealed that the studied calcite was subjected to progressive diagenesis. $\mathrm{MgO}$ content varies from 0.94 to $2.5 \%$. The terminal parts of the studied Tayiba Formation are more dolomitized relative to the middle beds. Though, it seems more eligible that the dolomitization process is controlled by the fracture and 
Table 1 Concentration of major (\%), trace, and rare earth elements (ppm) of the studied carbonate rocks as well as ratios

\begin{tabular}{|c|c|c|c|c|c|c|c|c|c|c|c|}
\hline Element & 1 & 2 & 3 & 4 & 5 & 6 & 7 & 8 & Min. & Max. & Average \\
\hline $\mathrm{CaO}$ & 26.62 & 25.73 & 27.1 & 25.94 & 27.54 & 25.41 & 24.95 & 27.8 & 24.95 & 27.8 & 26.39 \\
\hline $\mathrm{MgO}$ & 1.77 & 1.81 & 1.54 & 0.94 & 1.99 & 2.1 & 2.4 & 2.5 & 0.94 & 2.5 & 1.88 \\
\hline $\mathrm{SiO}_{2}$ & 26.75 & 26.63 & 25.31 & 27.37 & 25.14 & 24.7 & 26.4 & 25.1 & 24.7 & 27.37 & 25.93 \\
\hline $\mathrm{Al}_{2} \mathrm{O}_{3}$ & 10.2 & 10.15 & 10.54 & 10.94 & 12.15 & 9.85 & 11.2 & 10.34 & 9.85 & 12.15 & 10.67 \\
\hline $\mathrm{Fe}_{2} \mathrm{O}_{3}$ & 3.39 & 3.45 & 2.97 & 3.54 & 2.15 & 3.41 & 3.2 & 2.94 & 2.15 & 3.54 & 3.13 \\
\hline $\mathrm{Na}_{2} \mathrm{O}$ & 0.26 & 2.58 & 1.37 & 0.94 & 1.04 & 0.27 & 1.94 & 1.64 & 0.26 & 2.58 & 1.26 \\
\hline $\mathrm{K}_{2} \mathrm{O}$ & 0.71 & 0.62 & 0.82 & 0.74 & 0.51 & 0.75 & 0.84 & 0.56 & 0.51 & 0.84 & 0.69 \\
\hline $\mathrm{P}_{2} \mathrm{O}_{5}$ & 0.37 & 0.37 & 0.36 & 0.35 & 0.41 & 0.41 & 0.52 & 0.31 & 0.31 & 0.52 & 0.39 \\
\hline $\mathrm{TiO}_{2}$ & 0.68 & 0.67 & 0.65 & 0.61 & 0.75 & 0.81 & 0.75 & 0.67 & 0.61 & 0.81 & 0.70 \\
\hline $\mathrm{SrO}$ & 0.115 & 0.114 & 0.12 & 0.12 & 0.18 & 0.13 & 0.12 & 0.14 & 0.114 & 0.18 & 0.13 \\
\hline $\mathrm{SO}_{3}$ & 0.67 & 0.74 & 0.69 & 0.79 & 0.54 & 0.84 & 0.65 & 0.85 & 0.54 & 0.85 & 0.72 \\
\hline $\mathrm{Cl}$ & 0.11 & 0.12 & 0.1 & 0.11 & 0.17 & 0.16 & 0.18 & 0.18 & 0.1 & 0.18 & 0.14 \\
\hline LOI & 28.2 & 26.91 & 17.92 & 27.01 & 27.41 & 31.12 & 26.82 & 26.93 & 17.92 & 31.12 & 26.54 \\
\hline Norm. Dolom. & 8.1 & 8.28 & 7.04 & 4.3 & 9.1 & 9.61 & 10.98 & 11.44 & 4.3 & 11.44 & 8.61 \\
\hline V & 53.4 & 60 & 80 & 80.1 & 95 & 92 & 97 & 100 & 53.4 & 100 & 82.19 \\
\hline $\mathrm{Cr}$ & 59.6 & 50.3 & 60.4 & 40.6 & 71.2 & 75 & 78 & 80 & 40.6 & 80 & 64.39 \\
\hline $\mathrm{Mn}$ & 238.8 & 250.1 & 325.4 & 280.1 & 310 & 315 & 340 & 384 & 238.8 & 384 & 305.43 \\
\hline Co & 5.6 & 6.7 & 5.8 & 7.1 & 8.4 & 6.8 & 7.9 & 8.9 & 5.6 & 8.9 & 7.15 \\
\hline $\mathrm{Ni}$ & 47.2 & 50.3 & 61.4 & 62.8 & 71.52 & 68 & 79 & 90 & 47.2 & 90 & 66.28 \\
\hline $\mathrm{Cu}$ & 10.1 & 10.5 & 12.4 & 15.3 & 16.4 & 15.2 & 17.3 & 17.9 & 10.1 & 17.9 & 14.39 \\
\hline$Z n$ & 109.1 & 120 & 112.8 & 151.2 & 165 & 105 & 164 & 134 & 105 & 165 & 132.64 \\
\hline Mo & 3.5 & 4.2 & 5.7 & 5.9 & 6.2 & 4.8 & 6.4 & 7.9 & 3.5 & 7.9 & 5.58 \\
\hline $\mathrm{Zr}$ & 129.4 & 135.1 & 140.8 & 159 & 145 & 159 & 164 & 179 & 129.4 & 179 & 151.41 \\
\hline $\mathrm{Pb}$ & 7.6 & 8.6 & 9.1 & 10.1 & 12 & 11.4 & 12.9 & 16.1 & 7.6 & 16.1 & 10.98 \\
\hline $\mathrm{Rb}$ & 19 & 20 & 25 & 30 & 24 & 26 & 29 & 32 & 19 & 32 & 25.63 \\
\hline Ga & 11.4 & 12.5 & 14.3 & 12.3 & 13.7 & 13.2 & 14.2 & 15.4 & 11.4 & 15.4 & 13.38 \\
\hline $\mathrm{Se}$ & 2 & 3 & 3 & 4 & 5 & 3 & 4 & 6 & 2 & 6 & 3.75 \\
\hline $\mathrm{Br}$ & 2.5 & 3 & 4 & 5.5 & 5.4 & 3.1 & 4.7 & 4.5 & 2.5 & 5.5 & 4.09 \\
\hline Y & 19.1 & 20.2 & 19.8 & 24.3 & 27.4 & 20.4 & 24.1 & 28.5 & 19.1 & 28.5 & 22.98 \\
\hline $\mathrm{Nb}$ & 13.7 & 15.4 & 16.2 & 14.8 & 17.2 & 18.7 & 15.4 & 16.4 & 13.7 & 18.7 & 15.98 \\
\hline As & 3.9 & 4.5 & 6.2 & 4.8 & 7.1 & 5.4 & 4.7 & 7.5 & 3.9 & 7.5 & 5.51 \\
\hline $\mathrm{Te}$ & 2.1 & 2.5 & 2.3 & 3.7 & 3.9 & 3.1 & 4.2 & 3.8 & 2.1 & 4.2 & 3.20 \\
\hline $\mathrm{Sb}$ & 4.1 & 4.5 & 5.1 & 4.8 & 5.7 & 2.5 & 3.1 & 3.8 & 2.5 & 5.7 & 4.20 \\
\hline I & 23 & 25 & 27 & 29 & 30 & 29 & 25 & 34 & 23 & 34 & 27.75 \\
\hline $\mathrm{Cs}$ & 7 & 8 & 6 & 9 & 8 & 8 & 7 & 8 & 6 & 9 & 7.63 \\
\hline $\mathrm{Ba}$ & 162.7 & 170.5 & 180.3 & 185 & 190 & 189 & 172 & 201 & 162.7 & 201 & 181.31 \\
\hline La & 27.4 & 28.5 & 29 & 30 & 35 & 37 & 25 & 40 & 25 & 40 & 31.49 \\
\hline $\mathrm{Nd}$ & 13.1 & 15.2 & 12.4 & 13.9 & 16.7 & 14.8 & 15.1 & 17.2 & 12.4 & 17.2 & 14.80 \\
\hline $\mathrm{Sm}$ & 17.4 & 18.4 & 20.3 & 19.7 & 21.8 & 19.9 & 20.2 & 22.7 & 17.4 & 22.7 & 20.05 \\
\hline $\mathrm{Hf}$ & 0.3 & 0.4 & 0.3 & 0.5 & 0.6 & 0.4 & 0.5 & 0.6 & 0.3 & 0.6 & 0.45 \\
\hline Sc & 24 & 22 & 27 & 26 & 27 & 31 & 32 & 35 & 22 & 35 & 28.00 \\
\hline W & 15.8 & 16.8 & 17.6 & 17.9 & 18.4 & 18.1 & 14.9 & 19.2 & 14.9 & 19.2 & 17.34 \\
\hline $\mathrm{Ti}$ & 2 & 2 & 3 & 2 & 2 & 2 & 3 & 3 & 2 & 3 & 2.38 \\
\hline $\mathrm{Ce}$ & 15 & 18 & 19 & 22 & 25 & 26 & 25 & 27 & 15 & 27 & 22.13 \\
\hline
\end{tabular}


Table 1 Concentration of major (\%), trace, and rare earth elements (ppm) of the studied carbonate rocks as well as ratios (Continued)

\begin{tabular}{|c|c|c|c|c|c|c|c|c|c|c|c|}
\hline Element & 1 & 2 & 3 & 4 & 5 & 6 & 7 & 8 & Min. & Max. & Average \\
\hline U & 1.1 & 1.3 & 1.7 & 2.1 & 2.3 & 2.1 & 2.4 & 3.4 & 1.1 & 3.4 & 2.05 \\
\hline Th & 8.6 & 7.9 & 9.3 & 10.2 & 10.4 & 9.4 & 8.4 & 10.8 & 7.9 & 10.8 & 9.38 \\
\hline $\mathrm{Ta}$ & 4 & 3 & 2 & 4 & 4 & 3 & 4 & 4 & 2 & 4 & 3.50 \\
\hline U/Mo & 0.31 & 0.31 & 0.3 & 0.36 & 0.37 & 0.44 & 0.38 & 0.43 & 0.31 & 0.43 & 0.37 \\
\hline V/Mo & 15.26 & 14.29 & 14.04 & 13.58 & 15.32 & 19.17 & 15.16 & 12.66 & 15.26 & 12.66 & 14.74 \\
\hline $\mathrm{V} /(\mathrm{V}+\mathrm{Cr})$ & 0.47 & 0.54 & 0.57 & 0.66 & 0.57 & 0.55 & 0.55 & 0.56 & 0.57 & 0.56 & 0.60 \\
\hline$\Sigma$ LREEs & 84.30 & 92.60 & 95.00 & 97.90 & 112.20 & 110.90 & 99.50 & 122.30 & 84.3 & 122.3 & 101.84 \\
\hline$\Sigma$ HREES & 43.10 & 42.20 & 46.80 & 50.30 & 54.40 & 51.40 & 56.10 & 63.50 & 42.2 & 63.5 & 50.98 \\
\hline$\sum$ REES & 366.50 & 390.40 & 412.80 & 429.20 & 459.90 & 444.60 & 414.10 & 493.60 & 366.5 & 493.6 & 426.39 \\
\hline $\mathrm{La} / \mathrm{Ce}$ & 1.83 & 1.58 & 1.53 & 1.36 & 1.40 & 1.42 & 1.00 & 1.48 & 1.67 & 1.48 & 1.42 \\
\hline
\end{tabular}

joint systems in the area, which maintain access to the dolomitizing fluids. Consequently, the dolomitization process was controlled by the fracture and joint in the area, which preserve access to the dolomitizing fluids. This result agrees with $\mathrm{X}$-ray results.

$\mathrm{SiO}_{2}$ content in the studied samples ranges from 24.7 to $27.37 \%$ with an average of $25.93 \% . \mathrm{Al}_{2} \mathrm{O}_{3}$ content ranges from 9.85 to $12.15 \%$ with an average $10.67 \%$ (Table 1). The carbonate rocks of the studied succession record average 1.26 and $0.69 \%$, respectively of $\mathrm{Na}_{2} \mathrm{O}$ and $\mathrm{K}_{2} \mathrm{O}$. The positive relation between $\mathrm{SiO}_{2}$ and both $\mathrm{Al}_{2} \mathrm{O}_{3}$ and $\mathrm{K}_{2} \mathrm{O}$ (Table 2) can mainly be attributed to the clay content, which is detected by X-ray diffraction analysis. The Eocene marine basin of deposition was relatively alkaline, close to the landmass that supplied the basin of deposition by quartz and clays (Ibrahim et al. 2016).

$\mathrm{Fe}_{2} \mathrm{O}_{3}$ content of the studied carbonate sediments ranges from 2.15 to $3.54 \%$, averaging $3.13 \%$. The values for the Tayiba dolomite indicate the formation of dolomite in the near-surface oxidizing environment (Choquette and James, 1990, Loukina and Abou El-Anwar 1994 and Abou ElAnwar 2006 and Abou El-Anwar 2011). The positive correlation between $\mathrm{Fe}_{2} \mathrm{O}_{3}$ and $\mathrm{SiO}_{2}(r=0.56)$, suggests that iron is not completely associated with the terrigenous admixture but is rather a pigment. Also, the strong negative correlation between $\mathrm{Fe}_{2} \mathrm{O}_{3}$ and $\mathrm{Sr}(r=-0.90)$ indicates that there is no essential function of many microbes (Abou El-Anwar 2005, 2011, 2014 and Abou El-Anwar 2018a and Abou El-Anwar et al. 2017 and Abou El-Anwar 2018a, 2018b).

The strontium content of the studied carbonate rocks in the studied samples ranges from 964 to 1522 ppm, averaging $1099 \mathrm{ppm}$, which indicate late diagenetic resulting of dolomitization process (Veizer, et al., 1978 and Tucker and Wright 1990). The positive correlation between $\mathrm{Sr}$ and $\mathrm{Ca}(r=0.56)$ signified that calcite is still the main host of strontium in the studied carbonates (Table 2). The values of $\mathrm{Sr}$ content can be attributed to the long diagenetic history particularly the dolomitization stages. This agrees with the findings of Brand and Veizer (1980) and Abou El-Anwar (2005 and 2006).

The average $\mathrm{Sr}$ content suggests that the dolomitization process has taken place in marine environment (Brand and Veizer 1980 and Abou El-Anwar 2011). The strong negative correlation between $\mathrm{Sr}$ and $\mathrm{Na}(r=-0.15)$ indicates that $\mathrm{Na}$ does not couple with $\mathrm{Sr}$ during dolomitization. This is in disagreement with Moore and Chowdhury (1988), Loukina, et al., (2001), and Abou El-Anwar (2005 and 2006).

\section{Trace and rare earth elements}

Geochemical tools are used to identify and construe the parameters of normal environmental and origin. Thus, trace and REE elements are the most geochemical parameters that can be used to illustrate the paleo-climatic environments (Veizer and Mackenzie 2014 and Kamber, et al., 2014).

Carbonate rocks in the Tayiba Formation, Abu Zenima region, are highly enriched in trace elements $(\mathrm{Zn}=132.6$, $\mathrm{Ni}=66.3, \mathrm{I}=27.8$, and $\mathrm{Mo}=5.1$, ppm, Table 1 and Fig. 3 ) and highly to moderately rare earth elements $(\mathrm{La}=31.5$, Sc $=28, \mathrm{Y}=23, \mathrm{Sm}=20.1, \mathrm{~W}=17.3, \mathrm{Nb}=16, \mathrm{Cs}=7.6, \mathrm{As}=$ $5.5, \mathrm{Sb}=4.2$, and $\mathrm{Ta}=3.5 \mathrm{ppm}$, Fig. 4) compared with those of the UCC (Rudnick and Gao 2003).

The strong and moderate positive correlations between $\mathrm{Al}_{2} \mathrm{O}_{3}$ and all immobile elements of trace and rare earth elements (Table 2) reveal that these elements are concentrated during weathering processes (Fedo et al. 1996). Almost all the trace and rare earth elements show positive relation with each other in the study carbonate rocks. Thus, these elements may be associated with each other or with the heavy minerals rather than with dolomite and clay minerals (Abou El-Anwar 2018b).

The radioactivity elements in the studied carbonate rocks are ranging from 1.1 to 3.4 with average $2.05 \mathrm{ppm}$ for $U$ and from 7.9 to $10.8 \mathrm{ppm}$ for Th. Therefore, these contents are less than the allowed limits for radioactivity 

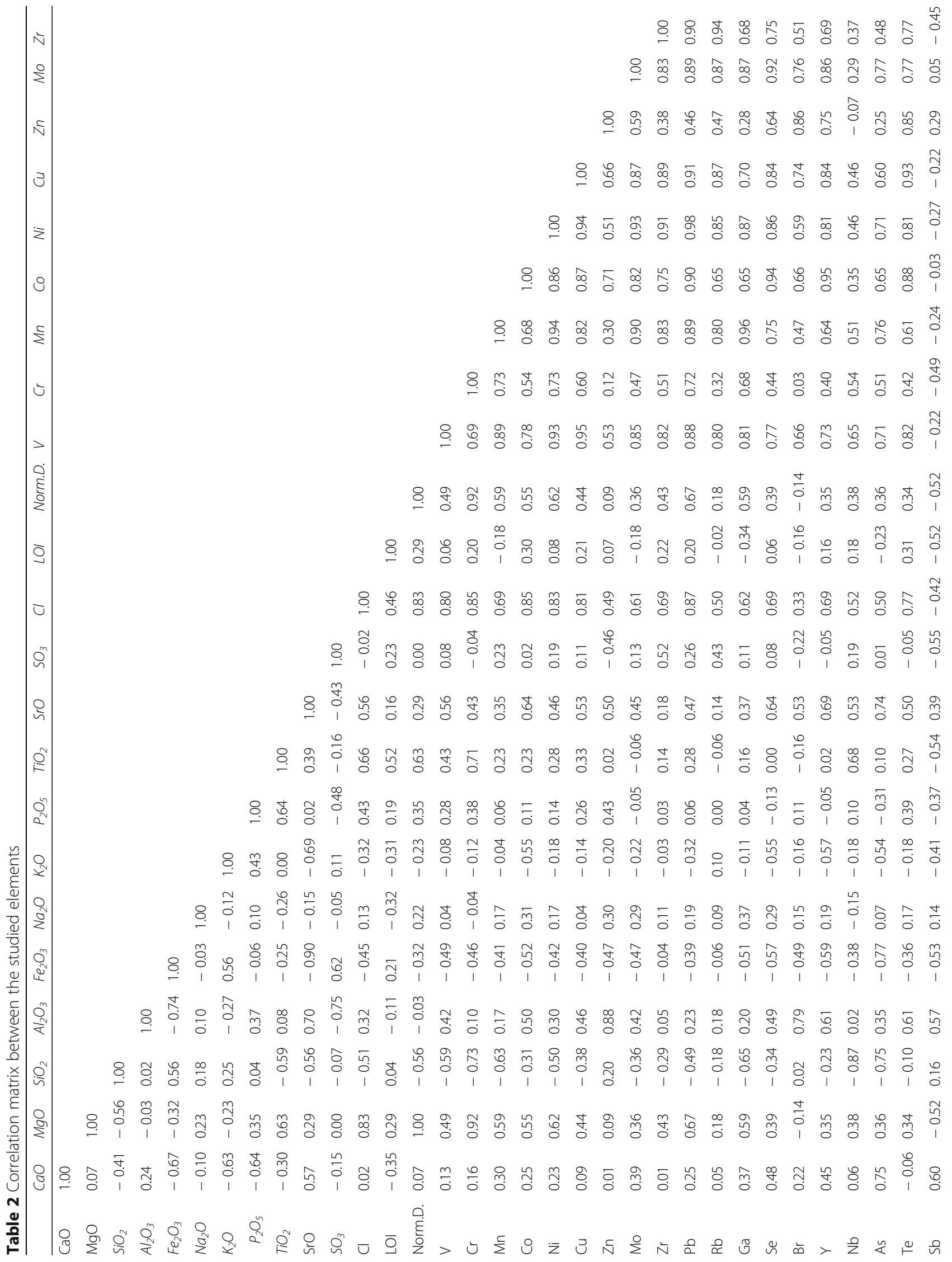


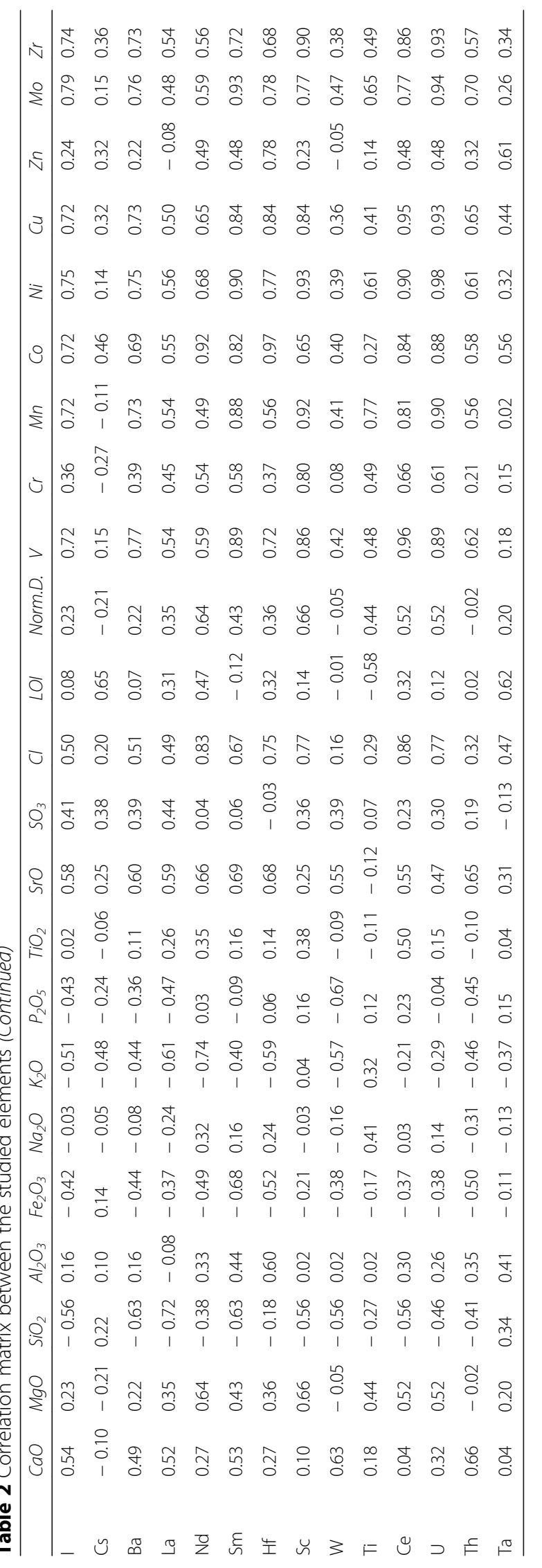




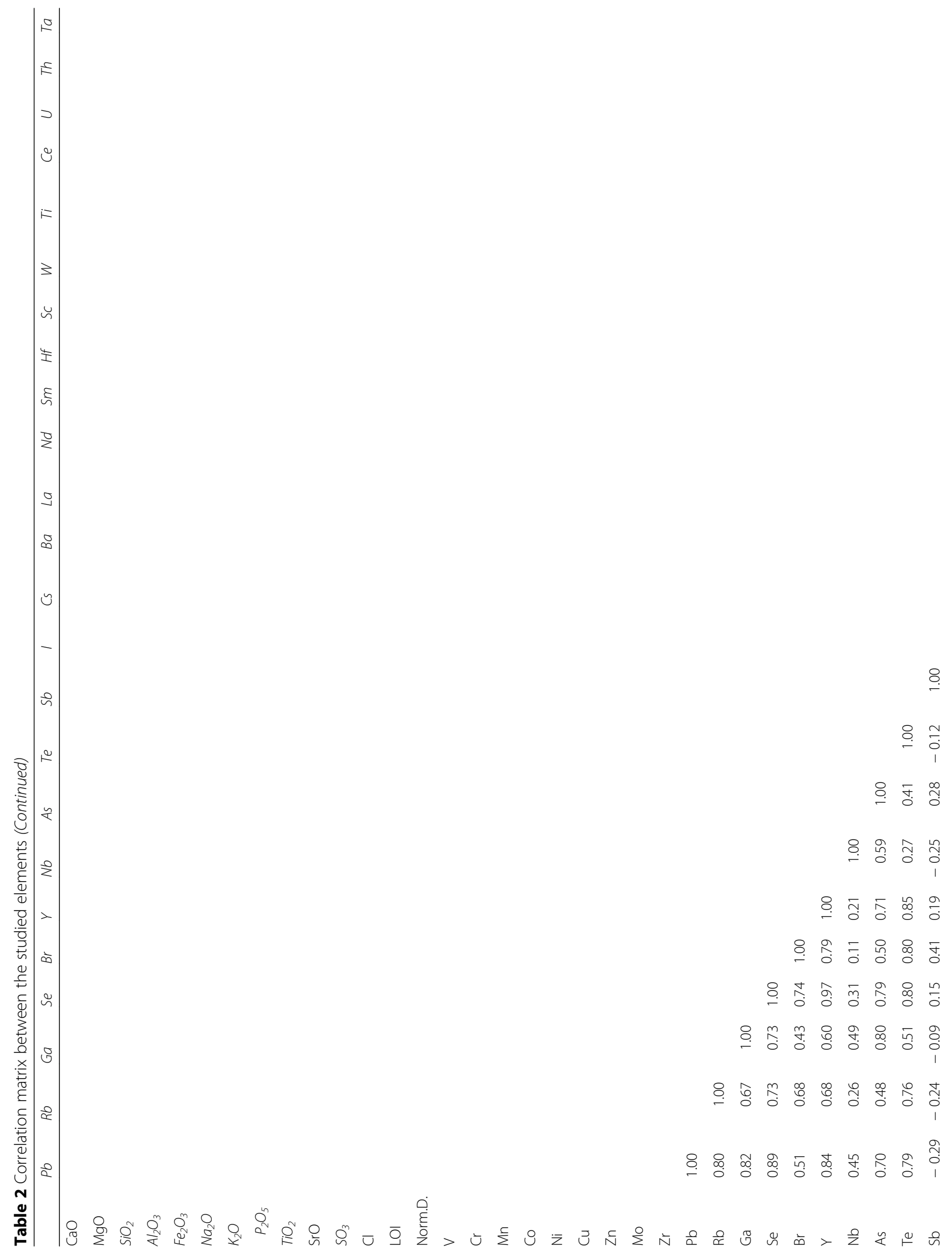




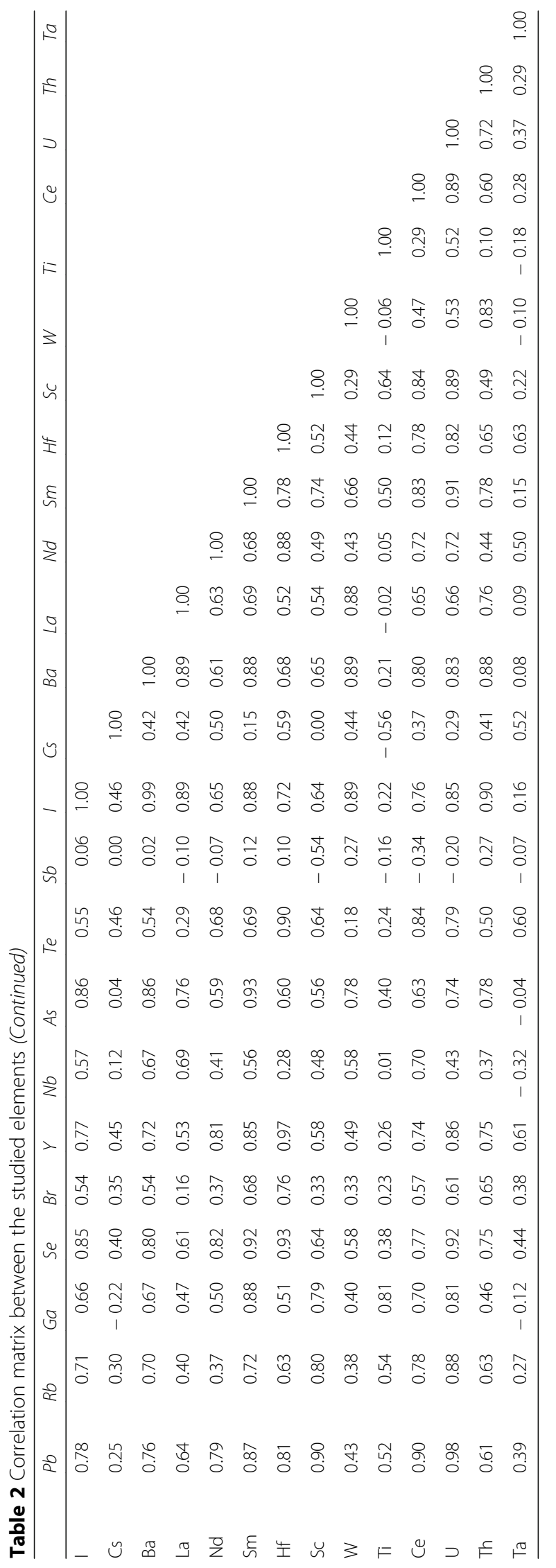




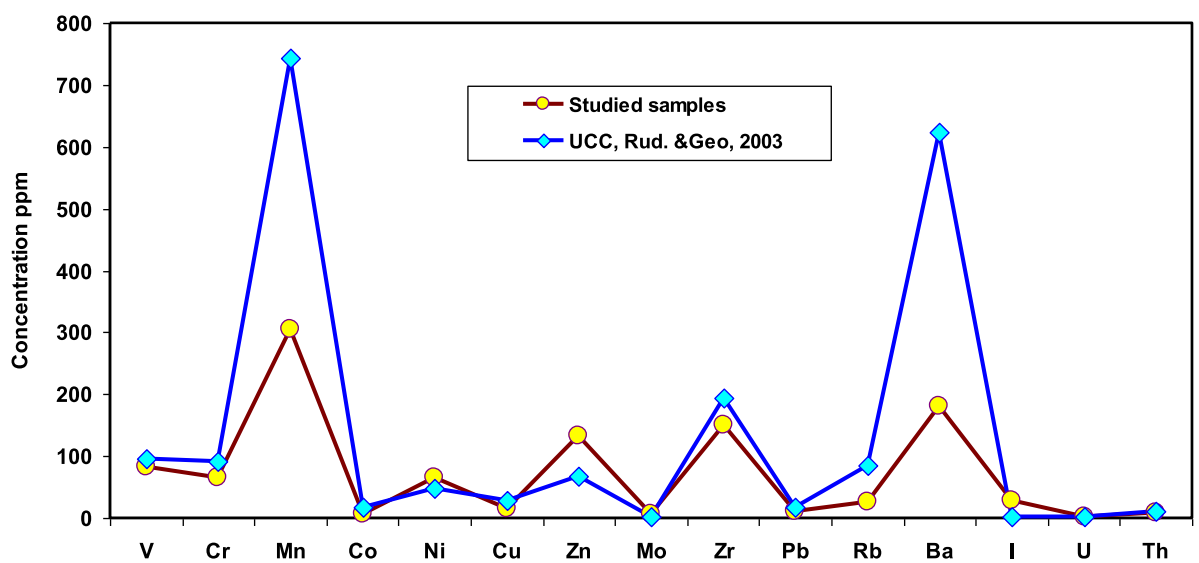

Fig. 3 The concentration of the trace elements of the studied carbonate rocks compared with the UCC (Rudnick and Gao 2003)

elements of carbonates. Thus, the studied carbonate rocks can be used in cement industries and as building stones (de Silva et al. 2010, Abou El-Anwar et al. 2017 and Abou El-Anwar 2018a).

\section{Environmental condition}

$\mathrm{Al}$ and $\mathrm{Mg}$ oxides are important scavengers for trace and REEs, which observed by the positive correlation among them and $\mathrm{Al}_{2} \mathrm{O}_{3}$ and $\mathrm{MgO}$. This finding indicates that the distribution of trace and REEs in the studied carbonate rocks is partly controlled by clays and dolomites.

Pi et al. (2014) mentioned that the content of redoxsensitive elements; $\mathrm{V}, \mathrm{Ni}, \mathrm{Mo}, \mathrm{U}, \mathrm{Cu}, \mathrm{Cr}, \mathrm{Re}, \mathrm{Cd}, \mathrm{Sb}, \mathrm{Tl}$, and $\mathrm{Mn}$ can be used to indicate paleo-oceanographic environments. The $\mathrm{V} / \mathrm{Mo}$ and $\mathrm{V} /(\mathrm{V}+\mathrm{Cr})$ ratios $(14.74$ and 0.6, respectively) Table 1 indicates that the studied carbonate rocks were deposited in oxic environments (cf. GallegoTorres et al. 2010; Pi et al. 2014 and Abou El-Anwar 2018a). U/Mo ratio (0.37) indicates the rocks of the studied area were deposited under an oxic marine transgressive condition (Arning et al. 2009 and Abou El-Anwar 2018b). Depletion of Ce (average $=22.1 \mathrm{ppm}$ ) indicated an anoxic environment (De Baar, et al., 1988). Consequently, the studied rocks deposited under anoxic to oxic environment.

The degree of digenesis can be increased during meteoric and burial diagenesis which was accompanied with loss of $U$ (under oxic conditions), and increase of $\mathrm{Zn}, \mathrm{Mn}$, and Fe (Halverson et al. 2007; Webb et al. 2009). Thus, depletion of $U$ and enrichment of $\mathrm{Zn}$ and Fe revealed that the deposition of the studied carbonates took place under oxic environment. In addition high content of $\mathrm{Sr}, \mathrm{Zn}$, and $\mathrm{Ni}$ as trace elements indicated that these carbonate rocks deposited in marine environments.

\section{Provence of carbonates}

Some of the elements are used to distinguish between deposits formed in freshwater, shallow-marine, and marine environments, as well as precipitated under surface

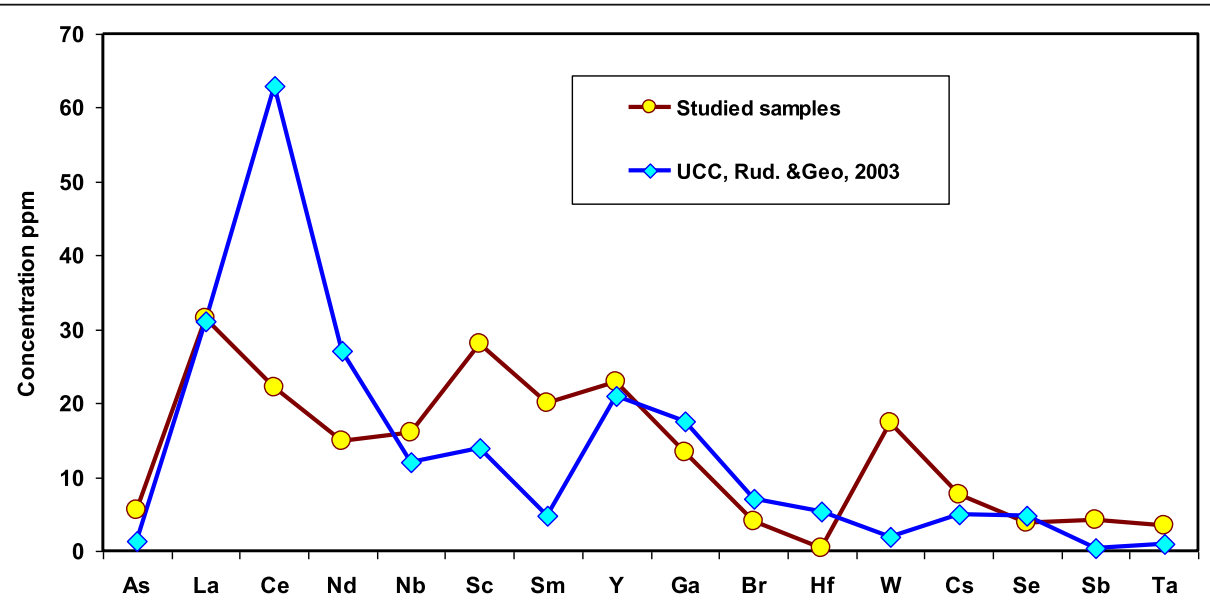

Fig. 4 The concentration of the rare earth elements of the studied carbonate rocks compared with the UCC (Rudnick and Gao 2003) 


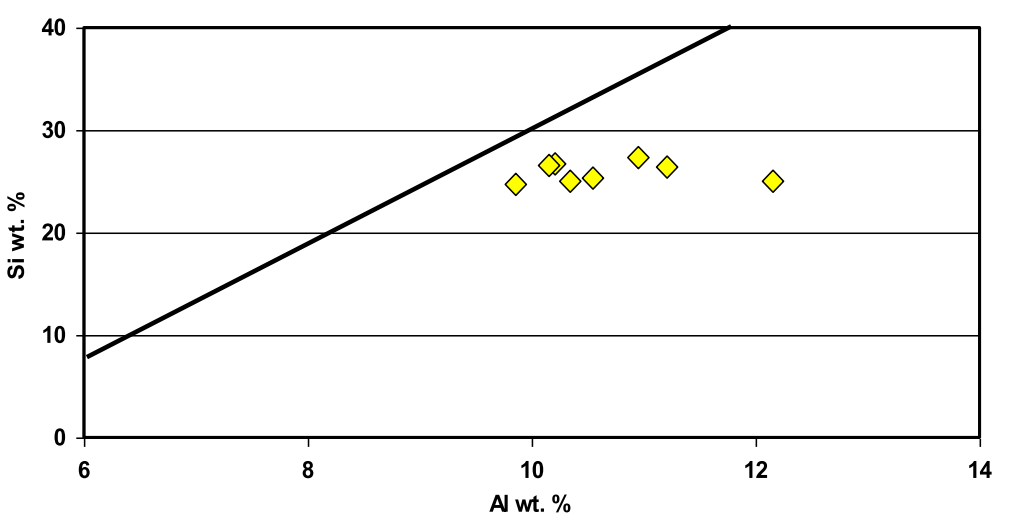

Fig. 5 Si-Al plot diagram after Choi and Hariya (1992)

or deeper condition. In addition to the rare earth elements, hydrogenous deposits show high $\Sigma$ REE and those of hydrothermal deposits are considerably lower (Usui and Someya 1997). The studied carbonate rocks show high $\Sigma$ REE (average of $426 \mathrm{ppm}$ ), compared with those of the total in average of continental crust which is about 125 ppm (Rudnick and Gao 2003). Moreover, Si$\mathrm{Al}$ discrimination diagram (Fig. 5) and the $(\mathrm{Ni}+\mathrm{Co})$ against $(\mathrm{As}+\mathrm{Cu}+\mathrm{Mo}+\mathrm{Pb}+\mathrm{V}+\mathrm{Zn})$ as a binary diagram (Fig. 6) according to Choi and Hariya (1992) and Nicholson (1992), respectively, indicated that the studied rocks are mainly hydrogenous sources. Low La/Ce ratios (1.42) and LREE enriched are suggest hydrogenous the origin of the studied carbonate rocks which conformed with Figs. 5 and 6 (Nath et al. 1997).

Trace and rare earth element geochemistry can be used as a tool for sediment provenance $(\mathrm{Hu}$, et al., 2017). The elements such as $\mathrm{Cr}, \mathrm{Sc}, \mathrm{Ta}, \mathrm{Th}, \mathrm{Zr}, \mathrm{Hf}$, As, and $\mathrm{Sb}$, as well as $\mathrm{Y}$ and the rare earth elements (REEs), $\mathrm{La}$ to $\mathrm{Lu}$ have little mobility in low-temperature, nearsurface environments, Thus, they can be useful tool for sediment provenance. $\mathrm{Fe}$ and $\mathrm{Cr}$ enrichment in pyroxenes and chromite, Sc present in pyroxenes, micas, amphiboles, titanite, and clay minerals, $\mathrm{Ti}$ and $\mathrm{Ta}$ are found in ilmenite, pyroxene, hornblende, and biotite. Th and
Ta can be hosted in micas, amphiboles, zircon, sphene, and clay minerals; $\mathrm{Zr}$ and $\mathrm{Hf}$ are associated with zircon, $\mathrm{As}$, and $\mathrm{Sb}$ most likely occurring as substitutes for Fe in magnetite; Sc is enriched in pyroxenes; and Th and La are enriched in granitic rocks. As a result, the trace and rare earth elements in the studied carbonate rocks may be derived from more mafic near sources.

The average of LREE enrichment than HREE $(\sim 102$ and $51 \mathrm{ppm}$, respectively) and the LREE/HREE ratio (2.00) indicated the effect of weathering process on the REE fractionation in the studied carbonate rocks. Thus, the low mobility of LREE than HREE leads to the LREE enrichment, while HREE depletion accompanying with increase weathering effect (Yusoff et al. 2013 and Cao, et al., 2016). Therefore, it is in compatible to the general distribution of REEs in limestone (Gromet et al. 1984; Condie 1991 and Ketris and Yudovich 2009).

The values of the $\mathrm{La}, \mathrm{Cs}, \mathrm{Sc}$, and Ga indicated that the investigated carbonate rocks were deposited in marine environment (Alibo and Nozaki 1999).

\section{Conclusions}

The closed correlation between the contents of REE and those of $\mathrm{Al}, \mathrm{Ca}$, and $\mathrm{Mg}$ is probably due to the vigorous role of calcite, dolomites, and clay minerals in the

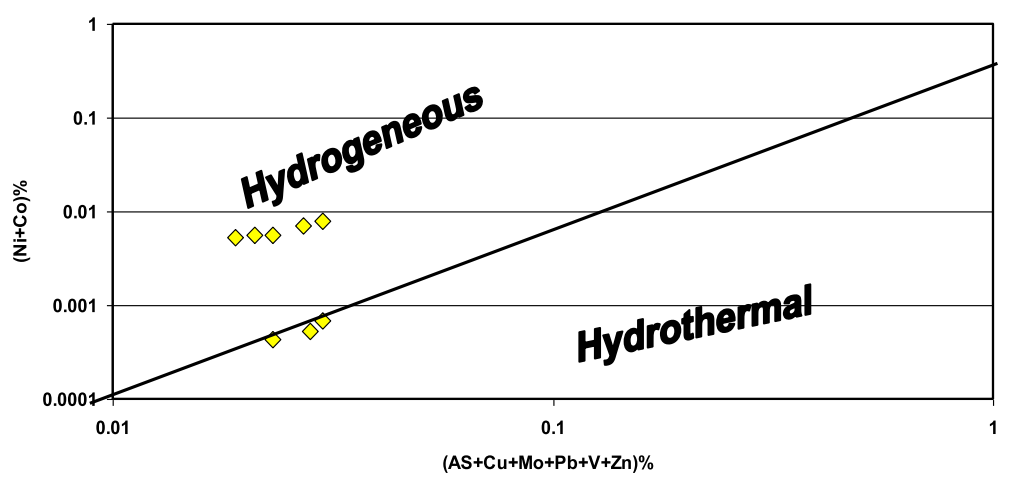

Fig. $6(\mathrm{Ni}+\mathrm{Co})$ versus $(\mathrm{As}+\mathrm{Cu}+\mathrm{Mo}+\mathrm{V}+\mathrm{Zn}$ ) plot diagram after Nicholson (19 92) 
transfer of REE in the carbonate rocks of Tayiba Formation (Upper Eocene) in Abu Zenima area, West Central Sinai. The studied carbonate rocks deposited under anoxic to oxic marine environments.

The low mobility of LREE than HREE in the studied carbonate rocks leads to the enrichment of LREE than HREE and complementary with increase weathering effect. The high concentration of the $\Sigma R E E$ and plot diagrams are indicated to hydrogenous source of the studied carbonate rocks.

\section{Acknowledgements}

The author would like to thank the Geological Sciences Dept., National Research Centre, for facilities during this work.

\section{Author's contribution}

The author read and approved the final manuscript.

\section{Funding}

No funding

\section{Availability of data and materials}

All data generated or analyzed during this study are included in this published article.

\section{Ethics approval and consent to participate}

Not applicable

\section{Consent for publication}

Not applicable

\section{Competing interests}

The author declares that there are no competing interests.

Received: 25 September 2019 Accepted: 21 November 2019

Published online: 30 December 2019

\section{References}

Abou El-Anwar EA (2005) Petrography, geochemistry and genesis of the Upper Eocene carbonate terraces (II and III), Qasr El-Sagha Formation, El-Faiyum, Egypt. Sedimentology of Egypt 13:243-260

Abou El-Anwar EA (2006) Petrography, geochemistry and genesis of some Middle Eocene rocks at Qattamia area, Cairo-Suez Road, Egypt. NRC, Egypt. 31(6):519-543

Abou El-Anwar EA. Petrographical, geochemical and diagenetic studies of the middle Eocene carbonates Mokattam Formation of Darb El-Fayium area. In: Int. Conf. on Geological Sciences and Engineering, Farance, Paris, Augustus 24-26, 2011; 80: 1315-1325

Abou El-Anwar EA (2014) Composition and origin of the dolostones of Um Bogma formation, Lower Carboniferous, West Central Sinai, Egypt. Carbonates Evaporates 29:239-250

Abou El-Anwar EA (2018a) Some carbonate rocks utilized as a building material rocks, Egypt Some carbonate rocks utilized as a building material rocks, Egypt, Carbonate and Evaporates, Accepted: 26. https://doi.org/10.1007/ s13146-018-0423-4

Abou El-Anwar EA. Lithologic characterization of the phosphorite bearing Duwi Formation (Campanian), South Esna, West Nile Valley, Egypt, Accepted: 25 February 2018, on line 2018b, Carbonates and Evaporites https://doi.org/10. 1007/s13146-018-0442-1

Abou El-Anwar EA, Mekky HS, and S. H. Abd El Rahim. Mineralogy, geochemistry, petrography, and depositional environment of Gebel El-Qurn, Early Eocene, West Luxor, South Egypt, Bulletin of the National Research Centre, 2018; 42:7, https://doi.org/10.1186/s42269-018-0008-3

Abou El-Anwar EA, Mekky HS, Abdel WW (2018) Geochemistry, mineralogy and depositional environment of black, shales of the Duwi Formation, Qusseir area, Red Sea coast, Egypt. Carbonates and Evaporites. https://doi.org/10. 1007/s13146-017-0417-7
Abou El-Anwar EA, Mekky HS, Darweesh HS, Aita SK (2017) Utilization of some Miocene Limestones as building materials from Egyptian north western coastal area (Abu- Sir Ridge). Carbonates Evaporates. https://doi.org/10.1007/ s13146-016-0326-1

Abul-Nasr RAA, Thunell RC (1987) Eocene eustatic sea level changes, evidence from western Sinai, Egypt. Palaeogeography, Palaeoclimatology, Palaeoecology 58:1-9

Alibo DS, Nozaki Y (1999) Rare earth elements in seawater: particle association, shale normalization, and Ce oxidation. Geochim. Cosmochim. Acta 63(3/4):363-372

Arning ET, Lückge A, Breuer C, Gussone N, Birgel D, Peckmann J (2009) Genesis of phosphorite crusts off Peru. Mar Geol. 262:68-81

Brand V, Veizer J (1980) Chemical diagenesis of a multicomponant carbonates systems. 1. Trace elements: J. Sed. Petrol. v. 50, p. 1219-1236.

Cao X, Wu P, Cao Z (2016) Element geochemical characteristics of a soil profile developed on dolostone in central Guizhou, southern China: implications for parent materials. Acta Geochim. 35(4):445-4

Choi JH, Hariya Y (1992) Geochemistry and depositional environment of Mn Oxide de-posits in the Tokoro Belt, Northeastern Hokkaido. Econ. Geol 87:1265-12 74

Choquette PW, James NP (1990) Limestone- the burial diagenetic environment In: Diagenesis (Ed. By I.A. Mcllreath and D.W. Morrow), Geoscience Canada Reprint Series, 4

Condie KC (1991) Another look at rare earth elements in shales. Geochim. Cosmochim. Acta 55:2527-2531

De Baar HJW, German CR, Elderfield H, Van Gaans P (1988) Rare earth element distributions in anoxic waters of the Cariaco Trench. Geochim. Cosmochim. Acta $52,1203-1219$

de Silva EF, Ammar M, Celso G, Fernando N, Abdelkrim C, Cristina S, Valdemar E, Ana R, Marques F (2010) Heavy elements in the phosphorite from Kalaat Khasba mine (North-western Tunisia): potential implications on the environment and human health. J. Hazard. Materials 182:232-245

El Barkooky AN, El-Araby A (1999) The Tertiary Red Beds of Abu Zenima area, West Central Sinai, Egypt: their stratigraphy and sedimentology. Proceedings of the Fourth International Conference on the Geology of the Arab World, pp 621-642

Fedo CM, Eriksson K, Krogstad EJ (1996) Geochemistry of shale from the Archean ( $3.0 \mathrm{Ga}$ ) Buhwa Greenstone belt, Zimbabwe: implications for provenance and source area weathering. Geochem Cosmic Acta 60(10):1751-1763

Gallego-Torres D, Martinez-Ruiz F, De Lange GJ, Jimenez-Espejo FJ, OrtegaHuertas M (2010) Trace-elemental derived paleoceano-graphic and paleoclimatic conditions for Pleistocene Eastern Mediterranean sapropels. Palaeogeogr Palaeoclimatol Palaeoecol 293(1):76-89

Gromet LP, Dymek RF, Haskin LA, Korotev RL (1984) The "North American shale composite": its compilation, major and trace element characteristics. Geochim. Cosmochim. Acta 48:2469-2482

Halverson GP, Dudás FÖ, Maloof AC, Bowring S.A. Evolution of the ${ }^{87} \mathrm{Sr} /{ }^{86} \mathrm{Sr}$ composition of neoproterozoic seawater. Palaeogeogr. Palaeoclimatol. Palaeoecol., 2007: 256 (3-4): 103-129

Hu J, Wang H, Wang M (2017) Provenance and tectonic setting of siliciclastic rocks associated with the Neoproterozoic Dahongliutan BIF: implications for the Precambrian crustal evolution of the Western Kunlun orogenic belt, NW China. J.Asian Earth Sci. 147, 95-115

Hume W, Madgwick T, Moon F, Sadek H (1920) Preliminary geologic report on Gabal Tanka area. Petroleum Research Bulletin 4. Cairo.

Ibrahim AM, Abou El Ezz AR, Mousa AS, El Hariri TYMA, El Ghany A (2016) A.A. Mineralogical and geochemical studies of Eocene Carbonate rocks at Wadi Tayiba and Wadi Feiran areas, Southwestern Sinai, Egypt. International J. Scient. Engin. Appl. Sci 2(2):279-304

Jackson CAL, Gawthorpe RL, Leppard CW, Sharp IR (2006) Rift-initiation development of normal fault blocks: insights from the Hammam Faraun fault block, Suez Rift, Egypt. Journal of the Geological Society of London 163:165-183

Kamber BS, Webb GE, Gallagher M (2014) The rare earth element signal in Archaean microbial carbonate: information on ocean redox and biogenicity. J. Geol. Soc. Lond. 171, 745-76

Ketris MP, Yudovich YE (2009) Estimations of clarkes for carbonaceous biolithes: world average for trace element contents in black shales and coals. Int. J. Coal Geol. 78:135-148

Loukina SM, Abou El-Anwar EA (1994) Geochemistry of Gebel Ataqa dolostones. Egypt. Geol. of Egypt 38:141-156

Loukina SM, Sameeh S, Abou El-Anwar EA (2001) Petrographical and geochemical characteristics of dolostones Of Gaber Formation (Pliocene), Ras Banas, Red Sea Coast, Egypt, Bull. NRC, Egypt, v. 26, (4), p. 525-540. 
Moore CH, Chowdhury A (1988) Upper Jurassic Samckover platform dolomitization northwestern Gulf of Mexico: a tale of two waters. In: V. Shukla and P.A. Baker (Eds), Sedimentology and Geochemistry of Dolostones, SEPM Special Publ., 43

Nath BB, Pluger WL, Roelandts I. Geochemical constraints on the hydrothermal origin of ferromanganese incrustations from the Rodriguez triple junction, Indian Ocean. In: Nicholson, K., Hein, J.R., Bühn, B., Dasgupta, S. (Eds.), Manganese mineralization: geochemistry and mineralogy of terrestrial and marine deposits. Geol. Soci. Lond. Spec. Publ, 1997; 119: 199-211.

Nicholson K (1992) Contrasting mineralogical-geochemical signatures of manganese oxides: guides to metallogenesis. Econ. Geol 87:1253-12 64

Pi DH, Jiang SY, Luo L, Yang JH, Hong-Fei Ling HF (2014) Depositional environments for stratiformwitherite deposits in the Lower Cambrian black shale sequence of the Yangtze platform, southern Qinling region, SW China: evidence from redox-sensitive trace element geochemistry. Palaeogeogr Palaeoclimatol Palaeoecol 398:125-131

Refaat AA, Imam MM (1999) The Tayiba Red Beds: transitional marine-continental deposits in the precursor Suez Rift, Sinai, Egypt. Journal of African Earth Sciences 26(3):467-506

Rudnick RL, Gao S (2003) Composition of the continental crust. Treatise Geochem 3:1-64

Tucker ME, Wright VP (1990) Carbonate sedimentology. Blackwell Scientific Publ. Oxford 482

Usui A, Someya M (1997) Distribution and composition of marine hydrogenetic and hydrothermal manganese deposits in the northwest Pacific. In: Nicholson K, Hein JR, Buhn B, Dasgupta S (eds) Manganese mineralization: geochemistry and mineralogy of terrestrial and marine deposits, Geol. Soci. Lond. Spec. Publ., vol 119, pp 177-198

Van Wagoner JC, Posamentier HW, Mitchum Jr, Vail PR, Sarg JF, Loutit TS, Hardenbol $J$. An overview of the fundamentals of sequence stratigraphy and key definitions. In: Wilgus, C.K., Hastings, B.S., Kendall, C.G.St.C., Posamentier, H.W., Ross, C.A., Van Wangoner, J.C. (Eds.), Sea level changes: an integrated approach. Society of Economic Paleontologists and Mineralogists (SEPM) Special Publication, 1988; 42: 39-46.

Veizer J, Lemieux J, Jones B, Gibling MR, Savelle J (1978) Paleosalinity and dolomitization of a lower paleozoic carbonate sequen. Can. J. Earth Sci., 15, 1448-1461

Veizer J, Mackenzie FT. Evolution of sedimentary rocks. In: Holland, H.D., Turekian, K.K. (Eds.), Treatise on geochemistry, 2nd ed. In: Mackenzie, F.T. (Ed.), Sediments, diagenesis, and sedimentary rocks, Elsevier-Pergamon, Oxford, 2014; 9: 399-435.

Webb GE, Nothdurft LD, Kamber BS, Kloprogge JT, Zhao JX (2009) Rare earth element geochemistry of scleractinian coral skeleton during meteoric diagenesis: a sequence through neomorphism of aragonite to calcite. Sedimentology 56:1433-1463

Youssef MI, Abdel Malik WM (1969) Micropaleontological zonation of the Tertiary rocks of the Tayiba-Feiran area, West- Central Sinai, Egypt. Proceeding of 6rh Arab Science Congress, Damascus:675-684

Yusoff ZM, Ngwenya BT, Parsons I (2013) Mobility and fractionation of REEs during deep weathering of geochemically contrasting granites in a tropical setting. Malaysia. Chem. Geol. 349:71-86

\section{Publisher's Note}

Springer Nature remains neutral with regard to jurisdictional claims in published maps and institutional affiliations.

\section{Submit your manuscript to a SpringerOpen ${ }^{\circ}$ journal and benefit from:}

- Convenient online submission

- Rigorous peer review

- Open access: articles freely available online

- High visibility within the field

- Retaining the copyright to your article

Submit your next manuscript at $\boldsymbol{\nabla}$ springeropen.com 